\title{
SOCIAL DEVELOPMENT OF CHILDREN UNDER-FIVE AS THE IMPACT OF EXTRAMARITAL PREGNANCY
}

\author{
Reni Purbanova1,3), Argyo Demartoto2), Bhisma Murti3) \\ 1)Academy of Nursing 17, Karanganyar, Central Java \\ 2)Faculty of Social and Political Sciences, Sebelas Maret University \\ 3)Masters Program in Public Health, Sebelas Maret University
}

\begin{abstract}
Background: Teenagers have a great curiosity of something have never been experienced before. This characteristic affect their sexual and dating behaviors. This eventually may lead to unwantted pregnancy, unsafe abortion, sexual transmitted disease (STD) infection, and even mortality. This study aimed to determine the social development of children under-five as the impact of extramarital pregnancy.

Subjects and Method: This was an explorative qualitative study. It was carried out in Jaten Subdistrict, Karanganyar District, Central Java. The key informants in this study included Head of the Office of Marital Affairs, Jaten

Subdistrict, Karanganyar District. Other key informants included extramarital offsprings, their parents and grandparents.

Results: Couples with extramarital pregnancy experience hard life. They tend to refuse the extramarital pregnancy and atempt to abort it. This situation affects parenting pattern. Social support system had an important role in parenting pattern. Couples lacking in social support system were not able to nurture the offsprings optimally. The offsprings received minimal stimuli required for the social development. In effect, their offsprings became shy and fearful.

Conclusion: Social support system has an important role in parenting pattern. It is required for the extramarital couples to raise their offsprings normally.
\end{abstract}

Keywords: extramarital pregnancy, offsprings, social development, parenting pattern

Correspondence:Reni Purbanova. Academy of Nursing 17, Karanganyar, Central Java. Email: purbanovareni1983@gmail.com.

Mobile: +6285658076583 . 